AL IBTIDA: JURNAL PENDIDIKAN GURU MI (2021) Vol 8 (1) : 16-31

DOI: http://dx.doi.org/10.24235/al.ibtida.snj.v8i1.8036

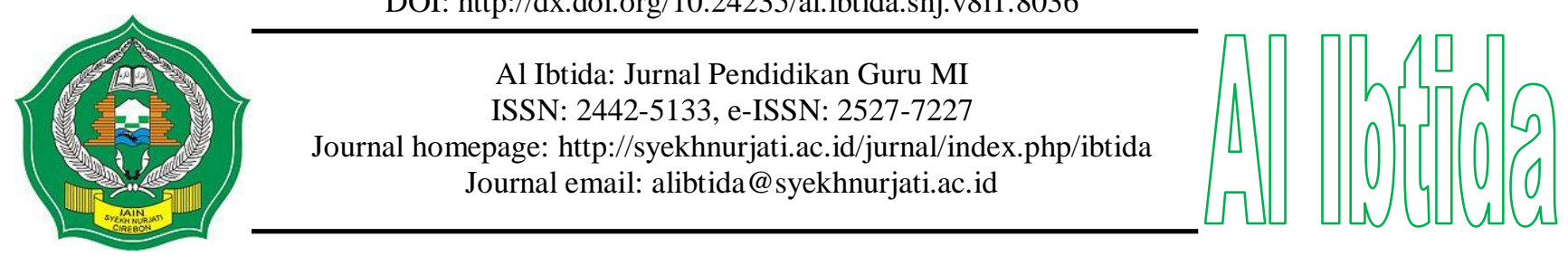

\title{
Aggressive Behaviour Among Adolescents with Mild Intellectual Disability: Do Parental Conflicts, Peer Influence, and Socio- Environmental Deprivation Play a Role?
}

\author{
Udeme Samuel Jacob* \\ *Postdoctoral Research Fellow, South African Research Chair in Education and Care in Childhood, \\ Faculty of Education, University of Johannesburg, South Africa \\ *Department of Special Education, Faculty of Education, University of Ibadan, Nigeria \\ Email: udeme01@gmail.com
}

\section{Jace Pillay**}

** South African Research Chair in Education and Care in Childhood, Faculty of Education, University of Johannesburg, South Africa

Email: jacep@uj.ac.za

\author{
Ifedolapo Oyewumi*** \\ ***Department of Special Education, Faculty of Education, University of Ibadan, Nigeria \\ Email: ifedolapooyewumi@gmail.com
}

Received: February 26 ${ }^{\text {th }}, 2021$. Accepted: June 02 ${ }^{\text {nd }}, 2021$. Published: June $27^{\text {th }}, 2021$.

\begin{abstract}
Aggressive behaviour is a major characteristics among adolescents with mild intellectual disability due to their inability to effectively use verbal communication to express their needs. This study, therefore, investigated the role of parental conflicts, peer influence, and socio-environmental deprivation in predicting aggressive behaviour among the study participants. The theory of planned behaviour, which states that individual behaviour is determined by corresponding expectations, was the theoretical framework used in this study. A descriptive correlational research design was adopted. The sample consisted of 50 participants (43\% males, $57 \%$ females) aged between 13 and 18 (median of 15.5; the standard deviation of 1.20). The participants were adolescents with mild intellectual disability who lived in the Ibadan Metropolis, Nigeria and were conveniently selected for the study. The Children's Perception of Inter-parental Conflict Scale, Resistance to Peer Influence Questionnaire, socioenvironment deprivation scale and Aggressive Behaviour Scale were used for data collection. Analysis of variance was used for data analysis. The results revealed that there was no significant relationship between the independent variables (parental conflicts, peer influence and socio-environmental deprivation) and aggressive behaviour among adolescents with mild intellectual disability. The joint contribution of parental conflict, peer influence and environmental deprivation to the aggressive behaviour was $5.5 \%$. This was not significant. The study has shown that parental conflicts, peer influence and socio-environmental deprivation do not play a role in increasing aggressive behaviour among adolescents with mild intellectual disability.
\end{abstract}

Keywords: aggressive behaviour, adolescents with mild intellectual disability, parental conflicts, peer influence, socio-environmental deprivation. 


\begin{abstract}
Abstrak
Perilaku agresif merupakan karakteristik utama pada remaja dengan disabilitas intelektual ringan karena ketidakmampuan mereka untuk menggunakan komunikasi verbal secara efektif untuk mengungkapkan kebutuhannya. Oleh karena itu, penelitian ini menyelidiki peran konflik orang tua, pengaruh teman sebaya, dan deprivasi sosial-lingkungan dalam memprediksi perilaku agresif di antara peserta penelitian. Teori perilaku terencana yang menyatakan bahwa perilaku individu ditentukan oleh ekspektasi yang sesuai merupakan kerangka teori yang digunakan dalam penelitian ini. Sebuah desain penelitian korelasional deskriptif diadopsi. Sampel terdiri dari 50 peserta (43\% laki-laki, $57 \%$ perempuan) berusia antara 13 dan 18 (median 15,5; standar deviasi 1,20). Para partisipan adalah remaja dengan disabilitas intelektual ringan yang tinggal di Ibadan Metropolis, Nigeria dan dipilih dengan mudah untuk penelitian ini. Persepsi Anak-Anak tentang Skala Konflik Antar Orangtua, Kuesioner Resistensi terhadap Pengaruh Teman Sebaya, skala deprivasi sosio-lingkungan dan Skala Perilaku Agresif digunakan untuk pengumpulan data. Analisis varian digunakan untuk analisis data. Hasil penelitian menunjukkan bahwa tidak ada hubungan yang signifikan antara variabel independen (konflik orang tua, pengaruh teman sebaya dan deprivasi sosial lingkungan) dengan perilaku agresif pada remaja dengan disabilitas intelektual ringan. Kontribusi bersama dari konflik orang tua, pengaruh teman sebaya dan perampasan lingkungan terhadap perilaku agresif adalah 5,5\%. Ini tidak signifikan. Penelitian telah menunjukkan bahwa konflik orang tua, pengaruh teman sebaya, dan deprivasi sosial-lingkungan tidak berperan dalam meningkatkan perilaku agresif di kalangan remaja dengan disabilitas intelektual ringan.
\end{abstract}

Kata kunci: perilaku agresif, remaja dengan disabilitas intelektual ringan, konflik orang tua, pengaruh teman sebaya, perampasan sosial lingkungan.

\title{
INTRODUCTION
}

One prevalent antisocial behaviour exhibited among adolescents with intellectual disability is that of aggression. The prevalence of aggressive behaviour in large populations of persons with intellectual disability is estimated to be between 10 and 15 per cent (Emerson et al., 2001; Holden \& Gitlesen, 2006; Jones et al., 2008). Adolescents with mild individual disability are likely to exhibit aggressive behaviour when their needs are not met with a constructive response because of their inability to delay gratification. Such behaviour can have significant implications for these adolescents, such as interference with development, quality of life, and barriers to social interaction (Holden \& Gitlesen, 2006). Most family and teachers find it stressful and emotionally difficult to deal with adolescents exhibiting aggressive behaviour (Hastings \& Brown 2002).

The resulting effect is that adolescents with mild intellectual disability are likely to remain aloof and excluded from mainstream learning and social interaction due to their immature and aggressive behaviour. Incidents of aggressive behaviour depend largely on the cognitive process. Individuals with disabilities, particularly adolescents with mild intellectual disability, are at greater risk of developing behavioural patterns that are both inappropriate 
and ineffective for social interaction (Hughes et al., 2012). Such behaviour is understood to have originated from inappropriate or incorrect modeling due to insufficient and inefficient interaction with group members. Other causal and maintaining mechanisms underlying aggressive behaviour are multifactorial (McClintock et al., 2003; Matson \& Boisjoli 2007).

Most adolescents with disabilities find participating in social activities with their peers and adults challenging due to the complexity of the social and emotional adjustments these interactions require. Although adolescents are considered more intellectually developed than children, this development can lead to changes in the reaction of adolescents to inter-parental conflict (Schulz et al., 2005). In addition, caregivers of adolescents with mild intellectual disability are more concerned about their future because the adolescents lack the ability to effectively control their anger and aggression. This not only results in pessimistic attitudes towards themselves but also to suffer from learned helplessness that can increase dissatisfaction (Ruthig et al., 2008; Dickhäuser et al., 2011). Various extrinsic factors influence aggressive behaviour towards self and others among adolescents with mild intellectual disability.

These include parental conflicts, peer influence, and social deprivation. For example, in most animal species, the result of a fight has a significant influence on individual aggression (Hsu et al., 2006; Rutte et al., 2006). The incentive for individuals to pursue and intensify antagonistic relationships after a victory increases together with the probability of overcoming their adversaries (winner's effect). By contrast, after a defeat, the propensity to display hostility towards others decreases with an increase in voluntary retreat due to fear of losing again (loser effect). Recent gains and losses will mediate aggressive behaviour (Huang et al., 2011; Lan \& Hsu, 2011). Parental conflict refers to disagreement that can lead to reciprocal love between parents, either declining or increasing. This reciprocal love can range from positive to negative (Goeke-Morey et al., 2007; Cummings et al., 2003).

Some parents exhibit what is known as suicidal dispute disposition. This is a pattern of behaviour in which parents do not directly disagree with each other but rather neglect and backstab one another. Children respond negatively and become involved in inter-parental conflicts when such behaviour is either disruptive or depressive (Du Rocher Schudlich et al., 2011). Different effects of destructive and proactive conflict styles on adolescents have been revealed by various research findings (McCoy et al., 2009; Davies et al., 2012). In these studies, questionnaires were administered by the researchers to parents while adolescents' responses to parents' discussion were observed. Emotional security, it was reported, acts as an intermediary between disruptive parental conflict and related psychological issues of children. 
At the other end of the continuum, however, there is evidence that the more proactive the action of the conflict (Tenneij \& Koot, 2008), the more favourable the reaction of an individual.

In the studies by Lopez Larrosa et al. (2009) and Cummings et al. (2003) questionnaires were filled out by parents and various situations discussed in the child's presence. In situations where proactive conflict resolution was adopted, the intervention of children was limited while they continued with their own activities. On the one hand, positive conflict behaviour has a significant association with improved ability to solve problems (Goodman et al., 1999). However, on the other hand, the more detrimental the conduct of the conflict, the more adverse the effects on the condition and behaviour of the adolescents. In particular, the findings revealed that parental conflicts could lead to maladjustment among adolescents, which has negative effects on their social, intellectual, educational and psycho-biological functioning (Cummings \& Davies, 2002; Zimet \& Jacob, 2001). In addition, the child's conduct was more aggressive when the conflicts were over the child itself or the marriage (Cummings et al., 2003; 2004).

Behavioural issues that arise during childhood and adolescence (specifically external challenges such as aggressive behaviour) can persist during adulthood, correlated with nonconformity to social norms, drug addiction and aggressiveness (Bongers et al., 2008). Moreover, peer influence may serve as the blueprint that influences behaviour while providing access, motivation and atmosphere suitable for interaction (Glaser et al., 2010). The influence of peers on dress, speech, substance abuse, sexual behaviour, aggressive behaviour, and violent and socially unacceptable behaviour of adolescents is significant (Padilla-Walker \& Bean, 2009; Tomé et al., 2008). Peers can influence adolescents through effective exchanges of thoughts and feelings that will help them develop appropriate conflict resolution skills. Moreover, not relating with peers can lead to social segregation and limited interaction with others because the opportunities of establishing new relationships are reduced.

The relationship between friendship and psychological well-being is positive (Glaser et al., 2010), whereas a hostile relationship with peers and health has a negative correlation (Laftman \& Östberg, 2006; Merckenet al, 2010). Resistance to peer influence increases with an increase in adolescent's autonomy from peer groups. This resistance tends to improve with age, which may suggest a relationship with adolescent maturity, and in most studies, boys are less resistance than girls (Sumter et al., 2009). Harmful and healthy behaviour can be encouraged by peer influence (Brown et al., 2008) because an important role can be played by peers in decision-making. Findings have consistently revealed that peers significantly 
influence adolescent choices (Brechwald \& Prinstein, 2011; Veenstra et al., 2013). Increasing concerns about health risks linked with negative peer influence have contributed to research that focuses predominantly on risk-taking and anti-social behaviours (Albert et al., 2013; Padilla-Walker \& Bean, 2009; Sim \& Koh, 2003).

A significant relationship has been established between these behaviours and peer influence and social learning, which may also be instrumental in motivating the adoption of other types of behaviour among adolescents, such as prosocial behaviour (Allen \& Antonishak, 2008; Telzer et al., 2013). Investigation of social factors resulting in aggression towards self and others is of considerable importance. Studies conducted to investigate social factors that increase the tendency of adolescents with mild intellectual disability to exhibit aggressive behaviour have identified socioeconomic disparities, poverty, and the environment (Okami \& Shackelford, 2001). The risk of being aggressive towards self and others can increase for adolescents who often experience deprivation of basic capabilities. The tendency to use aggression to resolve conflicts when confronted with challenging circumstances is higher among adolescents who were abused. For instance, sexually harassed adolescents are twice as vulnerable to experience different forms of conduct disorder in their interactions with others (Cyr et al., 2006; Lewis \& Fremouw, 2001).

The risk of disruptive behaviour increases among adolescents who spend most of their time in the community where limited access to the social world (Beaver et al., 2009). Adolescents with mild intellectual disability are usually excluded from social and learning activities because of low self-control and increased impulsive behaviour. Moreover, they are excluded from pro-social groups due to their poor verbal skills and limited pool of solutions to address their social problems. Adolescents whose parents are excessively permissive are more likely to indulge in crime, alcohol usage and substance abuse with a high propensity to socialise with delinquent peers.

Evans \& Saegert (2000) and Schraiber et al. (2006) investigated the key socioenvironmental variables that increase aggressive behavior. They concluded that socioeconomic disparities, family income, difficulty in providing for the health, educational qualification, housing and security needs of the general population play a significant role. From a social point of view, more individuals with aggressive behaviour have a deficiency processing socially acceptable information; that is, their ability to process, interpret and evaluate behaviour as either risky or of benefit is limited (Bennett et al., 2005; Schraiber et al., 2006). In addition, adolescents who are either punished or rewarded inconsistently or 
whose parents constantly engage in conflict are likely to face challenges in developing the skills required to cope effectively with social problems.

The theory of planned behaviour (TPB) (Ajzen, 1991) was the theoretical framework for the study. This theory maintains that an individual's behaviour is determined by corresponding expectations. The TPB is, therefore, essential for predicting and defining the social conduct an individual chooses in a given situation (Ajzen et al., 2004; Michel et al., 2014). Although the present study investigated aggressive behaviour among adolescents with mild intellectual disability, the TPB was chosen as a framework because it provides a perspective for the exploration and evaluation of cross-cultural and individual differences in behavioural intention. Thus behaviour is distinguished by perception and normative criteria that are unique to an individual. However, considering the vast number of studies that have been motivated by TPB over the years, little attention has been devoted to this interaction hypothesis (Yzer \& van den Putte, 2014).

The major setback of TPB is the requirement that the actions under review be open to subjective norms (Fishbein \& Ajzen, 1975), which substantially restrict the suitability of the theory. Although the speculative mediating determinants of perceived behavioral control are conceptually persuasive and logically based, their investigation has rarely received any empirical support. This failure may largely be due to methodological difficulties (Ajzen, 2002; Fishbein \& Ajzen, 2010; Yang-Wallentin et al., 2004). One major problem is that the interaction effect is significant to the distribution of the predictor and moderator variables. Peer influence and environment have, however, largely been described as intra-individual concepts that correlate with individual observable behavioural patterns and intention (Morris, Marzano, Dandy, \& O'Brie, 2012). This study aims to investigate the role of parental conflicts, peer influence, and socio-environmental deprivation in predicting aggressive behaviour among the study participants

\section{METHODS}

The study adopted the descriptive correlational research design. Fifty adolescents with mild intellectual disability $($ male $=43 \%$, female $=57 \%)$ aged between 13 and $18(\mathrm{M}=15.5$; $\mathrm{SD}=1.20$ ) were purposively selected from five special schools for learners with intellectual disability in Ibadan Metropolis, Oyo State, Nigeria. The convenient sampling technique was used to select respondents due to the unique attributes of adolescents with mild intellectual disability. The whole population identified as having mild intellectual disability was used as respondents for the study. In addition to the demographic characteristics collected from 
respondents, such as information on age, gender and years of schooling, the measures discussed below were also used for data collection in the study.

The Children's Perception of Inter-parental Conflict scale (CPIC) (Grych et al., 1992) was a 48-item scale which consisted of three factors: conflict properties $=17$ items; threat to self $=14$ items; and self-blame $=13$ items. The CPIC was a three-point Likert scale: $1=$ False; 2 = Sort of true; 3 = True. The more incidents of Inter-parental conflicts were demonstrated by higher scores on the scale. The scale measured the attitudes, perspectives, and reactions of adolescents to inter-parental conflict. Revalidation of the CPIC scale among 10 adolescents in Ibadan Metropolis yielded a Cronbach's alpha of 0.82.

The socio-environmental scale (SENSE) had 20 items which were used for the collection of socio-environmental information. It was designed by the researcher. Key factors on the scale were: socioeconomic disparities $=8$; poverty $=9$; and environment $=8$. The SENSE was a five-point Likert scale: 1 = strongly agree; 2 = agree; 3 = undecided; $4=$ disagree; and $1=$ strongly disagree. Revalidation of the SENSE scale among 10 adolescents in Ibadan Metropolis yielded a Cronbach's alpha of 0.88.

The Resistance to Peer Influence questionnaire consisted of 10-items were used to collect information on resistance to peer influence (RPI) (Steinberg \& Monahan, 2007). Each item was subdivided into two. First, respondents were required to choose an option that best described the group they interacted with most (i.e., more vs less peer resistant). Next, they were asked to indicate the degree to which they were influenced by the group (i.e., really true vs sort of true). The combination of the two sub-items formed an aggregate of a 4-point Likert-type scale. The nonresistant group was tagged as 1, while the resistant group was tagged as 4. Furthermore, the total RPI is generated by summing up the choices made for the 10 items, the higher the scores, the higher RPI. Psychometric properties of the RPIQ was appropriate respectable criterion validity (Steinberg \& Monahan, 2007) and reliability (i.e., internal consistency; Cronbach's $\alpha$ s > .70; Steinberg \& Monahan, 2007; Sumter et al., 2009).

The aggressive behaviour scale (ABS) was a 4-item summary that measured verbal aggression (screaming at others), physical assault (hitting others), socially unacceptable and destructive behaviour (throwing things), and resistance to care (shoving of caregivers). The frequency of ABS items was coded over 7 days as not exhibited (0); behaviour occurred 1 to 3 days over the past 7 days (1); behaviour occurred 4 to 6 days over the past 7 days, but not more than daily (2); or behaviour occurred daily (3) (Andres et al., 2017). ABS scores ranged from 0 to 12 , with higher scores suggesting most behaviours occurred at a higher frequency. 
The average inter-rater reliability estimates for all behaviour items on the MDS 2.0 was excellent, with a kappa of 0.72 (Morris et al., 1997).

Enlisted respondents for the study were adolescents identified as having mild intellectual disability because of the need to provide responses to questions asked while the research tick appropriately on the questionnaire. Those whose intelligent quotient level ranged between 52 and 68, based on screening by a psychologist using the Slosson intelligence convenient sampling technique, were selected as respondents for the study. The consent of respondents, parents or caregivers, and school administrators was sought for participation in the study. Respondents were appropriately informed about the intent of the study, while explicit instruction was given to guide them about what to expect. Respondents were assured of the confidentiality of the responses provided for the study. Teachers and support staff in the selected schools also assisted in organising the respondents. Each respondent spent an average of 45 minutes filling out the questionnaire. Permission to collect information for the research was obtained from the relevant education district in Ibadan Metropolis. Having submitted the approval to the school head, a teacher was assigned to assist each participant in securing parental or caregiver consent because of their age. Research ethics were adhered to for the study. The data generated were analysed at 0.05 level of significance. The joint contributions and relative effects made by parental conflict, peer influence and social deprivation were determined using regression analysis.

\section{RESULTS AND DISCUSSION}

Research question 1: Does parental conflict, peer influence and environmental deprivation have a significant relationship with aggressive behaviour among pupils with intellectual disability?

Table 1. Mean, standard deviation, and correlational matrix of variables used for regression analysis

\begin{tabular}{ccccccc}
\hline Variables & $\mathrm{M}$ & $\mathrm{SD}$ & 1 & 2 & 3 & 4 \\
\hline $\mathrm{PC}$ & 13.52 & 7.62 & 1 & & & \\
$\mathrm{PI}$ & 11.41 & 4.14 & .143 & 1 & & \\
$\mathrm{SD}$ & 14.16 & 2.08 & -.074 & -.007 & 1 & \\
$\mathrm{AB}$ & 14.26 & 1.78 & -.183 & -.062 & .265 & 1 \\
\hline
\end{tabular}

$\mathrm{PC}=$ parental conflict, $\mathrm{PI}=$ peer influence, $\mathrm{ED}=$ social deprivation, and $\mathrm{AB}=$ aggressive behaviour

Table 1 indicates the relationship between parental conflict, peer influence and environmental deprivation) and aggressive behaviour. As revealed, aggressive behaviour had no significant relationship with parental conflict $(r=-.183 ; p>.05)$, peer influence $(r=-.062$; $p>.05)$ and social deprivation $(r=.265 ; p>.05)$. This implies that the independent variables 
did not have a significant relationship with aggressive behaviour among pupils with intellectual disability.

Research question 2: Does parental conflict, peer influence and social deprivation make a significant joint contribution to aggressive behaviour among adolescents with mild intellectual disability?

Table 2: Summary of regression analysis of the joint contribution of parental conflict and social deprivation to aggressive behaviour among adolescents with mild intellectual disability

\begin{tabular}{|c|c|c|c|c|c|c|}
\hline Model & $\mathbf{R}$ & R Square & Adjus & Square & \multicolumn{2}{|c|}{ Std. Error of the Estimate } \\
\hline 1 & .235 & .053 & \multicolumn{2}{|c|}{-.008} & & \\
\hline \multicolumn{7}{|c|}{ a. Predictors: (Constant), Aggressive behavior } \\
\hline \multicolumn{7}{|c|}{ ANOVA } \\
\hline \multicolumn{2}{|l|}{ Model } & $\begin{array}{c}\text { Sum of } \\
\text { Squares }\end{array}$ & Df & Mean Square & $\mathbf{F}$ & Sig. \\
\hline \multicolumn{2}{|c|}{ Regression } & 165.08 & 3 & 51.36 & .857 & .468 \\
\hline \multicolumn{2}{|c|}{1 Residual } & 2631.54 & 45 & 58.47 & & \\
\hline \multicolumn{2}{|l|}{ Total } & 2785.633 & 48 & & & \\
\hline
\end{tabular}

Table 2 shows parental conflict, peer influence, and social deprivation had no significant contribution to aggressive behaviour among adolescents with mild intellectual disability $\left(F_{(3 ; 45)}=.857 ; p=.468>.05\right)$; hence the null hypothesis $(2)$ was accepted. The result did, however, indicate a multiple regression square of .053 , which implies that parental conflict, peer influence and social deprivation had a 5.3\% contribution to the aggressive behaviour of the adolescents with mild intellectual disability, though the contribution was not significant.

Research question 3: Does parental conflict, peer influence and social deprivation have a significant relative contribution to aggressive behaviour among pupils with intellectual disability?

Table 3: Summary of regression analysis of the relative contribution of parental conflict and social deprivation to aggressive behaviour among adolescents with mild intellectual disability

\begin{tabular}{|c|c|c|c|c|c|c|}
\hline \multirow{2}{*}{\multicolumn{2}{|c|}{ Model }} & \multicolumn{2}{|c|}{$\begin{array}{l}\text { Unstandardised } \\
\text { Coefficients }\end{array}$} & \multirow{2}{*}{$\begin{array}{c}\begin{array}{c}\text { Standardised } \\
\text { Coefficients }\end{array} \\
\text { Beta }\end{array}$} & \multirow[t]{2}{*}{$\mathbf{T}$} & \multirow[t]{2}{*}{ Sig. } \\
\hline & & $\mathbf{B}$ & $\begin{array}{l}\text { Std. } \\
\text { Error }\end{array}$ & & & \\
\hline \multirow[t]{4}{*}{1} & (Constant) & 24.978 & 11.811 & & 2.115 & .040 \\
\hline & Parental Conflict & .233 & .267 & .127 & .874 & .387 \\
\hline & Peer influence & -.060 & .625 & -.012 & -.247 & .537 \\
\hline & $\begin{array}{l}\text { Social } \\
\text { Deprivation }\end{array}$ & -.783 & .645 & -.183 & -1.213 & .232 \\
\hline
\end{tabular}

Dependent variable: Aggressive behaviour 
Table 3 shows the relative contribution of parental conflict and social deprivation to aggressive behaviour among adolescents with mild intellectual disability using the standardized beta weights and $p$-values. The result showed no significant relative contribution of parental conflict (beta $=.127 ; p=.387>.05)$, peer influence $($ beta $=-.012 ; p=.537>.05$ ) and social deprivation (beta $=-.183 ; p=.232>.05$ ) to aggressive behaviour among adolescents with mild intellectual disability. This implies that none of the independent variables in the model had a relatively significant contribution to the dependent variable.

The roles of parental conflicts, peer influence, and social deprivation on aggressive behaviour among adolescents with mild intellectual disability have not been investigated in the literature. Based on the theoretical framework used in the theory of planned behaviour (Ajen, 1991), the role of parental conflicts, peer influence, and social deprivation on aggressive behaviour among 50 adolescents with mild intellectual disability in Nigeria was investigated. The role of parental conflicts on aggressive behaviour was observed not to be significant. A representative sample of adolescents with mild intellectual disability was used as respondents in this study. The importance of this study is because about 16 per cent of the world's population is challenged by one form of disability or the other (Raub et al., 2016), while in Nigeria, 13.37 per cent of the country's population are disabled (Arimoro \& Elgujja, 2019).

The research question of this review was: Does parental conflict, peer influence and social deprivation have a significant relationship with aggressive behaviour among pupils with intellectual disability? The current study brought to the fore that peer influence and social deprivation did not have a significant relationship with aggressive behavior. In contrast, parental conflict had a positive relationship with aggressive behaviour among adolescents with mild intellectual disability in this study. The findings of this study show that the relationship between parental conflicts and aggressive behaviour among study participants was not significant. This does not align with previous research submission (Davies et al., 2012; Du Rocher Schudlich et al., 2011; Cummings et al., 2003; Goeke-Morey et al., 2007; Lopez Larrosa et al., 2009; McCoy et al., 2009). The relationship was positive, though, which indicates that the more parental conflict there was, the more aggressive behaviour increased among pupils with intellectual disability. The reason for this inconsistency may be due to parents of adolescents with intellectual disability over-protecting them and preventing them from socializing with members of their extended family and community.

The findings of this study show that no relationship existed between the independent variables, peer influence and social deprivation, among adolescents with mild intellectual 
disability. This was not consistent with previous findings on peer influence (Padilla-Walker \& Bean, 2009; Tomé et al., 2008; Glaser et al., 2010) and social deprivation (Okami \& Shackelford, 2001; Laftman \& Östberg, 2006; Mercken et al., 2010). The relationship is, however, negative, which reveals that as peer influence and social factors decrease, aggressive behaviour also decreases. Peer influence and socio-environment deprivation may not have predicted aggressive behaviour among adolescents with mild intellectual disability because of their incomplete mental development. The incomplete mental development will result in difficulty to process behavioural norms appropriately.

This study found that parental conflicts, peer influence and social deprivation did not make a joint contribution to predicting aggressive behaviour among adolescents with mild intellectual disability. Thus, the finding does not support those of other studies (Laftman \& Östberg, 2006; Mercken et al., 2010; Tomé et al., 2008; Glaser et al., 2010). The third research question asked whether parental conflict, peer influence and social deprivation made a significant relative contribution to aggressive behaviour among pupils with intellectual disability. The results show that none of the independent variables made a significant contribution to the dependent variable. This was inconsistent with several studies (Brechwald \& Prinstein, 2011; Veenstra et al., 2013; Padilla-Walker \& Bean, 2009; Glaser et al., 2010, Raub et al., 2016). This could likely be the result of adolescents with intellectual disability having difficulty in using the adaptive skills required to adjust to changes in their environment and learn from social interaction.

\section{CONCLUSION}

This study has advanced that parental conflicts, peer influence and social deprivation do not have a relationship with aggressive behaviour among adolescents with mild intellectual disability. The findings of this research have revealed ideas and understanding of the effects of parental conflict, peer influence and social deprivation on the tendency to exhibit aggressive behavior among adolescents with mild intellectual disabilities. The findings of the study will also be used to assist parents, students, counseling psychologists, mental health practitioners, teachers and researchers in the identification of specific recommendations for minimising aggressive behaviour, and to find preventive measures to avoid the vulnerability of adolescents with mild intellectual disabilities to discrimination. This study did not investigate the effect of parental involvement, parenting styles and school factors as potential causal factors of aggressive behaviour. Another limitation was the number of respondents selected for the study. The reason for the small sample size was due to the unique 
characteristics of adolescents with mild intellectual disability, which made it difficult for their parents to show interest in enrolling them in school.

\section{FUNDING}

This work was supported by the South African Research Chairs Initiative of the Department of Science and Innovation and National Research Foundation of South Africa. South African Research Chair, Education and Care in Childhood, Faculty of Education, University of Johannesburg South Africa [grant number: 87300, 2017].

\section{REFERENCES}

Ajzen, I. (1991). The theory of planned behavior. Organised Behaviour and Human Decision Processes, $50(2)$ 179-211. https://www.dphu.org/uploadsattachements/books/books_4931_0.pdf

Ajzen, I. (2002). Residual effects of past on later behavior: Habituation and reasoned action perspectives. Personality and Social Psychology Review, 6(2), 107-122. https://doi.org/10.1207/S15327957PSPR0602_02

Ajzen, I., Brown, T.C., \& Carvajal, F. (2004) Explaining the discrepancy between intentions and actions: the case of hypothetical bias in contingent valuation. Personality and $\begin{array}{lllll}\text { Social Psychology } & \text { Bulletin, } & 30 & \text { (9), } & 1108-1121\end{array}$ https://doi.org/10.1177/0146167204264079

Albert, D., Chein, J., \& Steinberg, L. (2013). The teenage brain: Peer influences on adolescent decision making. Current Directions in Psychological Science, 22(2), 114-120. https://doi.org/10.1177/0963721412471347

Allen, J. P., \& Antonishak, J. (2008). Adolescent peer influences: Beyond the dark side. In M. J. Prinstein \& K. A. Dodge (Eds.), Understanding peer influence in children and adolescents (pp. 141-160). Guilford Press.

Andres, E., Kerling, F., Hamer, H., Kasper, B., \& Winterholler, M. (2017). Behavioural changes in patients with intellectual disability treated with perampanel. Acta Neurological Scandinavica, 136(6), 645-653. https://doi.org/10.1111/ane.12781

Arimoro, A. E., \& Elgujja, A. M. (2019) Persons with intellectual disability and access to justice in Nigeria: Challenges and the way forward. Yobe State University Law Review, 1(2), 73-96.

Beaver, K. M., Shutt, J. E., Boutwell, B. B., Ratchford, M., Roberts, K., \& Barnes, J. C. (2009). Genetic and environmental influences on levels of self-control and delinquent peer affiliation: results from a longitudinal sample of adolescent twins. Criminal Justice Behaviour, 36, 41-60.

Bennett, S., Farrington, D. P., \& Huesmann, R. (2005). Explaining gender differences in crime and violence: The importance of social cognitive skills. Aggression and Violent Behaviour, 10, 263-288. https://doi.org/10.1016/j.avb.2004.07.001

Bongers, I. L., Koot, H. M., Van der Ende, J., \& Verhulst, F. C. (2008). Predicting young adult social functioning from developmental trajectories of externalizing behaviour. Psychological Medicine, 38(7), 989-999. https://doi.org/10.1017/S0033291707002309 
Brechwald, W. A., \& Prinstein, M. J. (2011). Beyond homophily: A decade of advances in understanding peer influence processes. Journal of Research on Adolescence, 21(1), 166-179. https://doi.org/10.1111/j.1532-7795.2010.00721.x

Brown, B. B., Bakken, J. P., Ameringer, S. W., \& Mahon, M. D. (2008). A comprehensive conceptualization of the peer influence process in adolescence. In M. J. Prinstein \& K. A. Dodge (Eds.), Understanding peer influence in children and adolescents (pp. 1744). Guilford Press.

Cummings, E. M., \& Davies, P. T. (2002). Effects of marital conflict on children: Recent advances and emerging themes in process-oriented research. Journal of Child Psychology \& Psychiatry, 43(1), 31-63. https://doi.org/10.1111/1469-7610.00003

Cummings, E. M., Goeke-Morey, M. C., \& Papp, L. M. (2003). Children's responses to everyday marital conflict tactics in the home. Child Development, 74(6), 1918-1929. https://doi.org/10.1046/j.1467-8624.2003.00646.x

Cummings, E. M., Goeke-Morey, M. C., \& Papp, L. M. (2004). Everyday marital conflict and child aggression. Journal of Abnormal Child Psychology, 32(2), 191-202. https://doi.org/10.1023/B:JACP.0000019770.13216.be

Cyr, M., Mc Duff, P., \& Wright, J. (2006) Prevalence and predictors of dating violence among adolescent female victims of child sexual abuse. Journal of Interpersonal Violence, 21(8):1000-1017.

Davies, P. T., Martin, M. J., \& Cicchetti, D. (2012). Delineating the sequelae of destructive and constructive Inter-parental conflict for children within an evolutionary framework. Developmental Psychology, 48(4), 939-955. https://doi.org/10.1037/a0025899

Dickhäuser, O., Reinhard, M-A., \& Englert, C. (2011). “Of course I will ...”: The combined effect of certainty and level of expectancies on persistence and performance. Social Psychology of Education, 4, 519-528.

Du Rocher Schudlich, T. D., White, C. R., Fleischhauer, E. A., \& Fitzgerald, K. A. (2011). Observed infant reactions during live Inter-parental conflict. Journal of Marriage \& Family, 73(1), 221-235. https://doi.org/10.1111/j.1741-3737.2010.00800.x

Emerson, E., Kiernan C., Alborz, A., Reeves, D., Mason, H., Swarbrick, R., Mason, L., \& Hatton, C. (2001). The prevalence of challenging behaviors: A total population study. Research in Developmental Disabilities, 22(1), 77-93. https://doi.org/10.1016/s08914222(00)00061-5

Evans, G. W., \& Saegert, S. (2000). Residential crowding in the context of inner city poverty, In S. Wapner , J. Demick , C. T. Yamamoto , \& H. Minami (Eds.), Theoretical perspectives in environmental-behavior research (pp. 247-267). Kluwer Academic/Plenum Publishers.

Fishbein, M., \& Ajzen, I. (1975). Belief, attitude, intention and behavior: An introduction to theory and research. Addison-Wesley.

Fishbein, M., \& Ajzen, I. (2010). Predicting and changing behaviour: The reasoned action approach. Psychology Press.

Glaser, B., Shelton, H. K., \& van den Bree, M. (2010). The moderating role of close friends in the relationship between conduct problems and adolescent substance use. Journal of Adolescent Health, 47(1), 35-42. https://doi.org/10.1016/j.jadohealth.2009.12.022 
Goeke-Morey, M. C., Cummings, E. M., \& Papp, L. M. (2007). Children and marital conflict resolution: Implications for emotional security and adjustment. Journal of Family Psychology, 21(4), 744-753. https://doi.org/10.1037/0893-3200.21.4.744

Goodman, S. H., Barfoot, B., Frye, A. A., \& Belli, A. M. (1999). Dimensions of marital conflict and children's problem-solving skills. Journal of Family Psychology, 13(1), 33-45. https://doi.org/10.1037/0893-3200.13.1.33

Grych, J. H., Seid, M., \& Fincham, F. D. (1992). Assessing marital conflict from the child's perspective: The Children's Perception of Inter-parental Conflict Scale. Child Development, 63(3), 558-572. https://doi.org/10.2307/1131346

Hastings, R. P \& Brown, T (2002). Behavior problems of children with autism, parental selfefficacy, and mental health. American Journal on Intellectual and Developmental Disabilities, 107(3):222-32 8017(2002)107<0222:BPOCWA>2.0.CO;2 https://doi.org/10.1352/0895-

Holden, B., \& Gitlesen, J. P. (2006) A total population study of challenging behaviour in the county of Hedmark, Norway: Prevalence, and risk markers. Research in Developmental Disabilities, 27(4), 456-465 https://doi.org/10.1016/j.ridd.2005.06.001

Hsu, Y., Earley, R. L., \& Wolf, L. L. (2006). Modulation of aggressive behaviour by fighting experience: Mechanisms and contest outcomes. Biological Review, 81(1), 33-74. https://doi.org/10.1017/S146479310500686X

Huang, S-P., Yang, S-Y., \& Hsu, Y. (2011). Persistence of winner and loser effects depends on the behaviour measured. Ethology, 117(2), 171-180. https://doi.org/10.1111/j.14390310.2010.01856.x

Hughes, K., Bellis, M. A., Jones, L., Wood, S., Bates, G., Eckley, L., McCoy, E., Mikton, C., Shakespeare, T., Officer, A.. (2012) Prevalence and risk of violence against adults with disabilities: A systematic review and meta-analysis of observational studies, The Lancet, 379(9826), 1621-1629 https://doi.org/10.1016/S0140-6736(11)61851-5

Jones, S., Cooper, S. A., Smiley, E., Allan, L., Williamson, A., \& Morrison J. (2008) Prevalence of, and factors associated with, problem behaviors in adults with intellectual disabilities. The Journal of Nervous and Mental Disease, 196(9), 678-686. https://doi.org/10.1097/NMD.0b013e318183f85c

Laftman, S. B., \& Östberg, V. (2006). The pros and cons of social relations: An analysis of adolescents' health complaints. Social Science \& Medicine, 63(3), 611-623. https://doi.org/10.1016/j.socscimed.2006.02.005

Lan, Y-T., \& Hsu, Y. (2011). Prior contest experience exerts a long-term influence on subsequent winner and loser effects. Frontiers in Zoology, 8(28). https://doi.org/10.1186/1742-9994-8-28

Lewis, S. F., \& Fremouw, W. (2001). Dating violence: A critical review of the literature. Clinical Psychology Review, 21(1):105-127.

Lopez Larrosa, S. L., Escudero, V., \& Cummings, E. M. (2009). Preschool children and marital conflict: A constructive view. European Journal of Developmental Psychology, 6(2), 170-189. https://doi.org/10.1080/17405620600843247

Matson, J. L., Bamburg, J. W., Mayville, E. A., Pinkston, J., Bielecki, J., Kuhn, D., Smalls, Y., \& Logan, J. R. (2000). Psychopharmacology and mental retardation: A 10 year review (1990-1999). Research in Developmental Disabilities, 21(4), 263-296. https://doi.org/10.1016/S0891-4222(00)00042-1 
Matson, J. L. \& Boisjoli, J. A. (2007) Multiple versus maintaining factors of challenging behaviours as assessed by the QABF for adults with intellectual disabilities. Journal of Intellectual Disability Research, 32(1), 39-44. https://doi.org/10.1080/13668250601184689

McClintock, K., Hall, S., \& Oliver, C. (2003). Risk markers associated with challenging behaviours in people with intellectual disabilities: A meta-analytic study. Journal of Intellectual Disability Research, 47(6), 405-416. https://doi.org/10.1046/j.13652788.2003.00517.x

McCobb, D. P., Hara, Y., Lai, G-J., Mahmoud, S. F., \& Flügge. G. (2003). Subordination stress alters alternative splicing of the Slo gene in tree shrew adrenals, Hormones and Behavior, 43(1):180-186 https://doi.org/10.1016/s0018-506x(02)00010-7

McCoy, K., Cummings, E. M., \& Davies, P. T. (2009). Constructive and destructive marital conflict, emotional security and children's prosocial behavior. Journal of Child Psychology \& Psychiatry, 50(3), 270-279. https://doi.org/10.1111/j.14697610.2008.01945.x

Mercken, L., Snijders, T., Steglich, C., Vertiainen, E., \& de Vries, H. (2010). Dynamics of adolescent friendship networks and smoking behavior. Social Networks, 32(1), 72-81. https://doi.org/10.1016/j.socnet.2009.02.005

Michel, W., Wannes, H., \& Lara, H. (2014). Under pressure to sext? Applying the theory of planned behaviour to adolescent sexting. Behavioural and Information Technology 33(1), 86-98. https://doi.org/10.1080/0144929X.2013.837099

Morris, J., Marzano. M., Dandy, N., \& O'Brie, L (2012). Theories and models of behaviour and behaviour change, Forestry, sustainable behaviours and behaviour change: Theories, 1-27

Morris, J.N., Nonemaker, S., Murphy, K., Hawes, C., Fries, B. E., Mor, V., \& Phillips, C. (1997). A commitment to change: Revision of HCFA's RAI. Journal of the American Geriatrics Society, 45(8), 1011-1016. https://doi.org/10.1111/j.15325415.1997.tb02974.x

Okami, P., \& Shackelford, T. (2001) Human sex differences in sexual psychology and behaviorAnnual Review of Sex Research; 12,186-241. DOI: $10.1080 / 10532528.2001 .10559798$

Padilla-Walker, L. M., \& Bean, R. A. (2009). Negative and positive peer influence: Relations to positive and negative behaviors for African American, European American, and Hispanic adolescents. Journal of Adolescence, 32(2), 323-337. https://doi.org/10.1016/j.adolescence.2008.02.003

Raub, A., Latz, I., Sprague, A., Stein, M. A., \& Heymann, J. (2016). Constitutional rights of persons with disabilities: An analysis of 193 national constitutions. Harvard Human Rights Journal, 29, 203-240.

Rutte, C., Taborsky, M., \& Brinkhof, M. W. G. (2006). What sets the odds of winning and losing? Trends in Ecology \& Evolution, 21(1), 16-21. https://doi.org/10.1016/j.tree.2005.10.014

Ruthig, J. C., Perry, R. P., Hladkyj, S., Hall, N. C., Pekrun, R., \& Chipperfield, J. G. (2008). Perceived control and emotions: interactive effects on performance in achievement settings. Social Psychology of Education, 2, 161-180. 
Schraiber, L. B., D’Oliveira, A. F., Couto, M. T. (2006) Violência e saúde: estudos científicos recentes. Violence and health: recent scientific studies Rev Saude Publica, 40(n Spe):112-120. https://doi.org/10.1590/S0034-89102006000400016

Schulz, M. S., Waldinger, R. J., Hauser, S. T., \& Allen, J. P. (2005). Adolescents' behavior in the presence of Inter-parental hostility: Developmental and emotion regulatory influences. Development and Psychopathology, 17(2), 489-507. https://doi.org/10.1017/S0954579405050236

Sim, T. N., \& Koh, S. F. (2003). A domain conceptualization of adolescent susceptibility to peer pressure. Journal of Research on Adolescence, 13(1), 57-80.

Sumter, S. R., Bokhorst, C. L., Steinberg, L., \& Westenberg, M. P. (2009). The developmental pattern of resistance to peer influence in adolescence: Will teenagers ever be able to resist? Journal of Adolescence, 32(4), 1009-1021 https://doi.org/10.1016/j.adolescence.2008.08.010

Steinberg, L., \& Monahan, K. C. (2007). Age differences in resistance to peer influence. Developmental Psychology, 43(6), 1531-1543. https://doi.org/10.1037/00121649.43.6.1531

Telzer, E. H., Fuligni, A. J., Lieberman, M. D., \& Galvan, A. (2013). Ventral striatum activation to prosocial rewards predicts longitudinal declines in adolescent risk taking. Developmental Cognitive Neuroscience, 3, 45-52. https://doi.org/10.1016/j.dcn.2012.08.004

Tenneij, N. H., \& Koot, H. M. (2008). Incidence, types and characteristics of aggressive behaviour in treatment facilities for adults with mild intellectual disability and severe challenging behaviour. Journal of Intellectual Disability Research, 52(2), 114-124. https://doi.org/10.1111/j.1365-2788.2007.00968.x

Tomé, G., Matos, M., \& Dinis, A. (2008). Consumo de substâncias e felicidade nos adolescentes, Substance use and happiness in adolescents. In M. Matos (eds.) Consumo de Substâncias: Estilo de Vida? À Procura de um estilo? (pp. 127-164). Lisboa: IDT.

Veenstra, R., Dijkstra, J. K., Steglich, C., \& Van Zalk, M. H. W. (2013). Network-behavior dynamics. Journal of Research on Adolescence, 23(3), 399-412. https://doi.org/10.1111/jora.12070

Yang-Wallentin, F., Schmidt, P., Davidov, E., \& Bamberg, S. (2004). Is there any interaction effect between intention and perceived behavioral control? A meta-analysis and an evaluation with three estimation methods. Methods of Psychological Research Online, $8(2), \quad 127-157 . \quad$ Retrieved from http://citeseerx.ist.psu.edu/viewdoc/download;jsessionid=B2CB02537A9A6A7B8948 5D13D5A5079E?doi=10.1.1.574.3164\&rep=rep1\&type=pdf

Yzer, M., \& van den Putte, B. (2014). Control perceptions moderate attitudinal and normative effects on intention to quit smoking. Psychology of Addictive Behaviors, 28(4), 11531161. https://doi.org/10.1037/a0037924

Zimet, D. M., \& Jacob, T. (2001). Influences of marital conflict on child adjustment: Review of theory and research. Clinical Child and Family Psychology Review, 4(4), 319-335. http://dx.doi.org/10.1023/A:1013595304718 